\title{
PERFORMANCE OF THE NUCLEAR POWER PLANT CONDENSING UNIT
}

\author{
Egor Pavelyev ${ }^{1}$, and Sergey Lavrinenko ${ }^{1, *}$ \\ ${ }^{1}$ National Research Tomsk Polytechnic University, 634050 Tomsk, Russia
}

\begin{abstract}
In the article the analysis of the modernization of the condensing unit. Thermal calculations and design of the condensing unit of the Kalininskaya nuclear power plant was conducted. Extension of service life of the operating NPP power units is one of the most important tendencies of the modern stage of nuclear power engineering development and the most efficient funds investment for preserving generating capacities. The data indicate when modernizing the condensing unit, its cooling area was increased for about $4,000 \mathrm{~m}^{2}$ due to increasing number of tubes. In addition, tube geometrical dimensions were changed; the wall thickness was reduced from 1 and $2 \mathrm{~mm}$ to 0.7 and $1.25 \mathrm{~mm}$ respectively.
\end{abstract}

\section{Introduction}

Service life of first generations of the nuclear power plants (NPP) of the Soviet Union and Russia was determined by absence of actual operational data on the NPP equipment wear and tear, and economic aspects providing necessity of compensating expenses on construction and operation of NPPs [1,2], obtaining normative amount of profit and forming financial resources for subsequent decommissioning of NPPs.

Further operation experience of the Russian and foreign nuclear power plants provided basis for justifying a technical possibility of revising the power unit service life periods previously set. Comparison of expenses for service life extension of the operating NPPs with investments in construction of new generating capacities demonstrated obvious economic efficiency and attractiveness of investments in service life extension. As a result, long-term growth plans of the nuclear industry of Russia [3, 4] included extension of the operating NPP service life as one of the most important tendencies of the modern stage of nuclear power engineering development.

Processes of carbonate scale deposition on condenser heat-exchange surfaces (CHS) from oversaturated solutions of recirculating water of the closed-circuit cooling system (CCS) can be theoretically divided into several stages, separation of which is found quite impossible [5-9]. Increase of deposit amount in local overheating areas causes corrosion damages of the heat-exchange surfaces and can result in necessity to perform expensive works on repair and even replacement of a steam generator.

\footnotetext{
Corresponding author: serg86@tpu.ru
} 


\section{Numerical analysis}

For providing reliability and increasing steam generator lifetime, and improving reliability and efficiency of the secondary system power units of NPP with a pressurized water reactor PWR-1000 was made of the design and the thermal design of the condenser of the steam turbine K-1000-60/1500 of unit 1 of Kalinin NPP, using the following basic equations (16):

The equation of heat balance:

$$
Q=G \cdot \Delta h_{s} \cdot \eta=D \cdot \Delta h_{w}
$$

$G$ - consumption of steam, $\mathrm{kg} / \mathrm{s}$;

$\Delta h_{s}, \Delta h_{w}$ - enthalpy of steam, water, $\mathrm{kj} / \mathrm{kg}$;

$\eta$ - efficiency factor.

Number of tubes in the one water course:

$$
N=\frac{4 \cdot D \cdot v_{w}}{\pi \cdot d_{i n}^{2} \cdot w_{w}}
$$

$v_{w}$ - volume of water, $\mathrm{m}^{3} / \mathrm{kg}$;

$d_{\text {in }}$ - inner diameter of the tubes, $\mathrm{m}$;

$w_{w}$ - velocity of the water, $\mathrm{m} / \mathrm{s}$.

Heat transfer coefficient:

$$
K=\frac{1}{d_{a} \cdot\left(\frac{1}{\alpha_{1} \cdot d_{o u}}+\frac{1}{2 \cdot \lambda} \cdot \ln \left(\frac{d_{o u}}{d_{i n}}\right)+\frac{1}{\alpha_{2} \cdot d_{i n}}\right)+R}
$$

$d_{a}$ - average diameter of the tubes, $\mathrm{m}$;

$d_{\text {ou }}$ - outer diameter of the tubes, $\mathrm{m}$;

$\alpha_{1}$ - heat transfer coefficient during condensation of steam, $\mathrm{W} /\left(\mathrm{m}^{2} \mathrm{~K}\right)$;

$\alpha_{2}-$ heat transfer coefficient from tubes to water, $\mathrm{W} /\left(\mathrm{m}^{2} \mathrm{~K}\right)$;

$\lambda$ - thermal conductivity, $\mathrm{W} /(\mathrm{m} * \mathrm{~K})$;

$R$ - thermal resistance of a contaminated tube, $\left(\mathrm{m}^{2} \mathrm{~K}\right) / \mathrm{W}$.

The surface area of the heat exchange:

$$
F=\frac{Q}{K \cdot \Delta t_{a}}
$$

$\Delta t_{a}$ - average temperature difference, ${ }^{\circ} \mathrm{C}$.

The length of the tubes:

$$
L=\frac{F}{\pi \cdot d_{a} \cdot N}
$$

The diameter of the tube bundle:

$$
D_{t}=1.05 \cdot d_{o u} \cdot b \sqrt{\frac{N}{\Psi}}
$$

$b$ - relative pitch;

$\Psi$ - fill factor of the tube plate. 


\section{Practical implementation}

After that JSC "Energospetsmontazh" performed works on replacement of the tube systems. These works were performed on the existing condenser of the steam turbine K$1000-60 / 1500$ of power unit No. 1 of the Kalininsky NPP.

The works were performed during maintenance outage. The condensers with heat exchange tubes from copper-nickel alloy were replaced with condensers with corrosionresistant steel tubes with weight 33 tons and over $8 \mathrm{~m}$ long each. In addition, metal structures for demounting condensers, trestle bridge for condenser replacement, and support assemblies with total weight 19 tons were mounted.

The developed tube systems and assemblies of the modular design condenser of turbine plant K-1000-60/1500 of power unit No. 1 of the Kalininsky NPP shall provide for:

- excluding copper-containing alloys from the NPP secondary system equipment;

- reliability, safety and performance of the condenser tube systems and assem-blies, with extended service life of the NPP equipment being taken into account;

- hydraulic closeness of the condenser tube systems due to fastening tubes in outer tube sheets by expanding and welding; elimination of thermal stresses in places of "cooling tube - tube sheet" attachment with relative motion of the shell and tubes;

- growth of the design vapor pressure in the condenser (of vacuum) with the respective gain of the turbine plant generator output on terminals of the generator with steam turbine K-1000-60/1500 manufactured by JSC "Turboatom", being confirmed by testing conducted by an independent specialized body.

The condenser modernization included replacement of the old tube systems (tubes from copper-nickel alloy grade MNZH5-1 and outer and intermediate sheets from carbon steel grade Steel 20) with new tube systems - of module No. $1 \ldots 8$ of every shell, with side walls and bottoms, with collected, expanded and welded tubes (tubes from corrosion-resistant stainless steel grade TP316L).

\section{Comparative analyses}

Among all the parameters determining the condensing steam turbine operation mode, vapor pressure at the end of expansion - spent vapor pressure in the condenser (vacuum level) has the greatest influence on the turbine economical operation. Providing and maintaining the required vacuum in the condenser that ensures most economical operation of the turbine plant as a whole, is a very important task of the operating personnel. Therefore, increase of the vapor pressure in the condenser for $0.01 \mathrm{~kg} / \mathrm{cm}^{2}$ causes increase of a gross average heat rate of a unit for NPP turbine plant approximately for $1 \%$ for wet steam turbine plants approximately for $2 \%$ of the steam turbine nominal capacity.

The main criteria of the condensing unit operation, characterizing the equipment performance under given conditions (rate of condensation per sq. m. of condenser surface, cooling water flow rate and temperature, etc.) are spent vapor pressure in the condenser and temperature drop at the condenser output $\delta$ t (difference between spent vapor saturation temperature and cooling water temperature at the condenser output). 
Table 1. Comparative analysis of condensers K-45600 and K-49210.

\begin{tabular}{|c|c|c|c|}
\hline \multirow[b]{2}{*}{ Characteristic } & \multirow[b]{2}{*}{$\begin{array}{c}\text { Unit of } \\
\text { measurement }\end{array}$} & \multicolumn{2}{|c|}{ Condenser type } \\
\hline & & $\begin{array}{l}\text { K-45610 before } \\
\text { modernization }\end{array}$ & $\begin{array}{c}\text { K-49210 after } \\
\text { modernization }\end{array}$ \\
\hline Type & & $\begin{array}{l}\text { Surface, single- } \\
\text { pass, two-flow }\end{array}$ & $\begin{array}{l}\text { Surface, single- } \\
\text { pass, } \\
\text { two-flow }\end{array}$ \\
\hline \multicolumn{4}{|c|}{ Design cooling area in the condenser shells } \\
\hline F1 & & 12877 & 16403 \\
\hline $\mathrm{F} 2$ & $\mathrm{~m}^{2}$ & 16366 & 16403 \\
\hline F3 & & 16366 & 16403 \\
\hline Cooling tube length & $\mathrm{mm}$ & 8970 & 8970 \\
\hline Cooling tube effective length & $\mathrm{mm}$ & 8910 & 8910 \\
\hline Cooling tube type & & "one-piece" & "welded" \\
\hline Cooling tube assortment & $\mathrm{mm}$ & $\begin{array}{l}28 \times 1.0 \times 9000 \\
28 \times 2.0 \times 9000\end{array}$ & $\begin{array}{c}28 \times 0.7 \times 9000 \\
28 \times 1.25 \times 9000\end{array}$ \\
\hline $\begin{array}{l}\text { Number of cooling tubes in the } \\
\text { condenser }\end{array}$ & & 57360/960, incl.: & 61800/984, incl.: \\
\hline Shell No. 1: & & & \\
\hline $28 \times 1.0 \times 9000 / 28 \times 0.7 \times 9000$ & & 16160 & 20600 \\
\hline $28 \times 2.0 \times 9000 / 28 \times 1.25 \times 9000$ & & 304 & 328 \\
\hline Shell No. 2: & pc. & & \\
\hline $28 \times 1.0 \times 9000 / 28 \times 0.7 \times 9000$ & & 20600 & 20600 \\
\hline $\begin{array}{l}28 \times 2.0 \times 9000 / 28 \times 1.25 \times 9000 \\
\text { Shell No. 3: }\end{array}$ & & 328 & 328 \\
\hline $28 \times 1.0 \times 9000 / 28 \times 0.7 \times 9000$ & & 20600 & 20600 \\
\hline $28 \times 2.0 \times 9000 / 28 \times 1.25 \times 9000$ & & 328 & 328 \\
\hline $\begin{array}{l}\text { Fastening of cooling tubes in the } \\
\text { end (outer) sheets }\end{array}$ & & expansion & $\begin{array}{l}\text { expansion and } \\
\text { welding }\end{array}$ \\
\hline Number of passes / flows & & $1 / 2$ & $1 / 2$ \\
\hline Overall dimensions & & & $\begin{array}{l}\text { Installation in the } \\
\text { existing foundation }\end{array}$ \\
\hline Number of outer sheets & pc. & 2 & 2 \\
\hline
\end{tabular}

\section{Conclusion}

Extension of service life of the operating NPP power units is one of the most important tendencies of the modern stage of nuclear power engineering development and the most efficient funds investment for preserving generating capacities.

The data given in table No. 1 allow making a conclusion that when modernizing the condensing unit, its cooling area was increased for about $4,000 \mathrm{~m}^{2}$ due to increasing number of tubes in shell No. 1. In addition, tube geometrical dimensions were changed; the wall thickness was reduced from 1 and $2 \mathrm{~mm}$ to 0.7 and $1.25 \mathrm{~mm}$ respectively. It was necessary due to the lower thermal conductivity coefficient of stainless steel as compared to the copper-containing alloy previously used. Moreover, it should be noted that the condenser overall dimensions remained unchanged that is a very important parameter of modernization. 


\section{Acknowledgments}

The research was realized with financial support of Minobrnauki of Russia in framework of FTP "Research and development in prior direction of scientific-technological complex of Russia in 2014-2020 years”, unique R\&D identifier RFMEFI58114X0001.

\section{References}

1. N.N. Galashov, S.A. Tsibulskiy, Power Technology and Engineering: Sci. J. 48, (2015)

2. A.M. Zavalishen, S.L. Kim, V.V. Maltsev. The Higher Education Establishment Bulletin. Nuclear Industry 1 (2011)

3. Development Program for the nuclear power engineering of RF for $1998-2005$ and for the period until 2010 approved by Decree No. 815 of the Government of RF on 21.07.1998

4. Development strategy for the nuclear power engineering in the first half of XXI century approved by the Government of RF on 25.02.2000

5. D. Hasson, M. Avriel, W. Resnick, Ind. Eng. Chem. Fundam. 7, (1968)

6. J. Taborek, T. Aoki, R.B. Ritter. Chem. Eng. Prog. 68 (1972)

7. J. Taborek, T. Aoki, R.B. Ritter, et al. Chem. Eng. Prog. 68 (1972)

8. V.A. Ruppel, Yu.S. Tretyakova, S.V. Lavrinenko, et al. MATEC Web Conf. 37 (2015)

9. K. Larionov, S. Lavrinenko, V. Gubin, et al. XVth International Conference Linguistic and Cultural Studies: Traditions and Innovations (LKTI 2015), Procedia Social and Behavioral Sciences 206 (2015) 